\title{
White Saviorism in Game of Thrones Series
}

\author{
R Firdaus $^{1}$ and S R Rusdiarti ${ }^{2}$ \\ $\left\{\right.$ roihatul.firdaus@ui.ac.id, ${ }^{2}$ suriella@ui.ac.id\} \\ ${ }^{1,2}$ Universitas Indonesia
}

\begin{abstract}
Game of Thrones (GOT) is an adaptation series from a novel by George R. R. Martin entitled A Song of Ice and Fire. GOT tells about the struggle for the throne between clans which resulted in an endless war. As one of the people fighting over the throne, Daenerys Targaryen has her own strategy in winning the battle. She repeatedly tried to save the slaves, so she was dubbed the Breaker of Chains and Mhysa. In the context of the rescue, Daenerys appeared to be most prominent among the non-whites she rescued. The emergence of Daenerys as a savior of non-white people implies that the GOT series is loaded with the implementation of white saviorism. This study aims to describe the identity of the character Daenerys, and reveal the concept of white saviorism contained in the film. The analysis revealed that Daenerys was considered to have more power than others who were not white. The prominence of the character in this film is not only a strategy of white domination, but is also closely related to her political interests, especially the title Breaker of Chains and Mhysa which support her image as a just and powerful queen.
\end{abstract}

Keywords: Game of Thrones, White, Saviorism, Savior

\section{Introduction}

Game of Thrones (GOT) is a television series adapted from a novel by George R. R. Martin entitled A Song of Ice and Fire (ASOIAF). During its 8-year run on the HBO channel, the series was successful with numerous awards and high public appreciation. GOT tells about the struggle for the throne between clans which resulted in an endless war. As one of the people who fought over the throne, Daenerys Targaryen has a strategy to gain and maintain power. Daenerys repeatedly visited cities and conquered them. Not only that, she also tried to free the slaves in each city he visited. As a result of the release, Daenerys received support from the former slaves she released. And through the support of a large number of former slaves was able to deliver Daenerys to be queen in the city of Meereen.

The liberation mission carried out by Daenerys is related to the so-called white saviorism narrative. The media and the cinematic racial order are basic to the understanding of race relations in any society [6]. According to Hughey, examples of white savior narratives as contained in the films "Tarzan" and "The Free State of Jones". Hughey argues that both films highlight white characters whose innate sense of justice drives a tale of racial cooperation, nonwhite uplift, and white redemption [2]. The main point of the white savior film is the presence of a white person somewhere and he/she is trying to save non-white people. Richard 
Dyer argues that whiteness 'secures its dominance by pretending not to be anything in particular', by being the norm and thus invisible because of its apparent omnipresence (Dyer 1997, 44 via [12]).

This article aims to describe the identity of the character Daenerys Targaryen as the Breaker of Chains and Mhysa, and reveal the mission of the rescue and liberation of slaves to win power struggles.

Wilson argues that the white savior figure is usually a male marked with a charisma that legitimizes his position as a leader to a group of dark-skinned people in need of redemption [9]. In contrast to the opinions expressed by Wilson, in this article it is stated that the white savior is a woman. However, the characteristics as explained by Wilson, that white savior has certain charisma that can attract the sympathy of non-white people, are found in the Daenerys figure. GOT series and novel have been studied with white savior dan post-colonial discourse as the main focus. [4] discusses the novel A Song of Ice and Fire series consisting of the titles A Game of Thrones, A Clash of Kings, A Storm of Swords, A Dance with Dragons and A Feast for Crow. The author uses a post-colonial approach to analyze the character of Daenerys in the novel. The author doubts Daenerys' role as a white savior even though Daenerys is portrayed as white. The author argues that Daenerys failed to be categorized as a white savior because the cities she conquered turned into chaos when she was in power.

While [11] argues that Daenerys is a white savior based on her actions. When she freed the slaves, Daenerys did not discuss her actions with the people, but instead she sought advice from her advisor who was also a white man. The author focuses her research on three episodes of the GOT series entitled Mhysa, The Black of House and White, and Oathkeeper. More focused again, the author highlights the anger of former slaves when Daenerys executes one of them which is the title of her research.

Both [4] and [11] argue that there is a white savior narrative in the ASOIAF novel and its adapted series. And both consider that Daenerys failed to carry out her mission as a white savior because of the chaos that led to her decision. The difference, [4] used a post-colonial approach to analyze Daenerys. While in this research offers a new perspective in looking at a character named Daenerys and analyzed in terms of the concept of white saviorism. This study not only discusses the sentence that was put forward by Daenerys which contained the white savior narration, but also the conversation and people's perception of Daenerys who was considered as a savior in an ancient prophecy. In addition, the object of discussion is not limited to Daenerys' journey on the Essos continent where she freed slaves, but the author presents explorations to seasons 6 and 7 for deeper analysis [13].

\section{Research Method}

The object of this research is Game of Thrones series mainly in season 4, 5 and 6 where Daenerys inhabited and freed slaves on the Essos continent. The data sources of this study are: first, the conversation that took place between Daenerys and the people; second, conversations and people's perceptions about Daenerys; third, visuals or images that can be analyzed using the concept of white savior. This study is conducted by implementing Matthew Hughey's method on white savior. [9] The white savior narrative, Hughey (2010) argues, features "a group of lower-class, ...nonwhites (generally black and Latino/a) who struggle through the social order in general...yet through the sacrifices of a white [protagonist] they are transformed, saved and redeemed". 


\section{Results And Discussion}

In the GOT universe series, there are two continents named Essos and Westeros. Essos is described as an exotic continent, full of magical things, and inhabited by savage tribes. Whereas Westeros is a continent with high civilization. Humans have a clan system that allows them to regulate their people. Westeros people mostly worship the Old Gods and the New and the Seven. Whereas the Essos people knew the fire god named Lord of Light. The people of Essos have brown and black skin, while Westeros is white. This indicates that both are representations of Eastern and Western societies in the real world.The portrayal of Westeros is the creators' self-interpretation of the Western heritage, while Essos serves as the representation of the distant Orient [7].

George R. R. Martin described Daenerys as a young woman with pale skin, silver hair with purple eyes typical of the Targaryen family. When the ASOIAF novel was adapted into a television series, Emilia Clarke was appointed as someone playing the character of Daenerys. The British-born actress [3] has white skin like Daenerys' portrayal in the novel. The physical description of Daenerys is contained in the following quotations,

"Look at her. That silver-gold hair, those purple eyes." [8]

"Goose pimples rose on her pale skin as the coldness crept up her thighs." [8]

The Targaryens are the blood of the dragon, descended from the high lords of the ancient Freehold of Valyria, their heritage proclaimed in a striking (some say inhuman) beauty, with lilac or indigo or violet eyes and hair of silver-gold or platinum white. [8]

In some scenes, Emilia looks contrasted with other actors who act as slaves or former slaves. For example, in the GOT series, Daenerys freed slaves in the city of Yunkai. With her white physique, she was very prominent among the slaves, who were mostly brown and black. Then the slaves hailed her name and called him Mhysa which means mother. That indicates something, namely there is a white savior narration in the series. Andrew Gordon (2003: 33) defines white savior as, "the great leader who saves blacks from slavery or oppression, rescues people of color from poverty and disease, or leads Indians in battle for their dignity and survival." (via [6])

As a queen, Daenerys holds many prestigious titles. She claimed to be the first of her name (from her family's breed), the rightful heir to the Seven Kingdoms, the Andal race and the First Men. In addition, she was nicknamed the khaleesi (queen) of the Dothraki, breaker of chains, and the mother of dragons. This is stated in the following quote,

You stand in the presence of Daenerys Stormborn of House Targaryen. Rightful heir to the Iron Throne. Rightful queen of the Andals and the First Men. Protector of the Seven Kingdoms. The mother of dragons. The khaleesi of the Great Grass Sea. The unburnt. The breaker of chains. (S07E03, 00:09:44,561) [1]

The last title mentioned in the quote above is the Breaker of Chains, which means the liberator of slaves. Daenerys often said that title before she executed her enemy. As in the following quote,

I, Daenerys Stormborn of House Targaryen, first of my name, breaker of chains and mother of dragons, sentence you to die. (S07E05, 00:09:00) [1]

The title of Breaker of Chains carried by Daenerys is related to her conquests in the cities of Astapor, Yunkai, and Meereen. In their conquests in the area, Daenerys freed slaves who 
had been working for their masters. Slavery was indeed rife in these cities and slaves could not rise from the slump. That's when Daenerys appeared as a savior. The rescue mission carried out by Daenerys was related to what Hughey called the white man's burden. Hughey explains the term as, "white savior narratives build on the belief that whites are endowed with a special responsibility to assimilate and civilize people of color (Shohat \& Stam, 1994 via [5]. Even when Daenerys tried to conquer the city of Meereen, she claimed that she participated in bringing the slaves she freed in the cities of Astapor and Yunkai. As stated in the following quote,

First, I went to Astapor. Those who were slaves in Astapor, now stand behind me. Free. Next I went to Yunkai. Those who were slaves in Yunkai, now stand behind me. Free. Now I have come to Meereen. (S04E03, 00:53:28) [1]

Daenerys revealed to the people of Meereen that she was the savior of the slaves. And when she arrived at Meereen, she used the same narrative to win the hearts of the slaves at Meereen. Later when she succeeded in occupying the city of Meereen and acting as queen, the former slaves were one of her main supporting lines. They even called her Mhysa which means mother as a form of reciprocation. This increasingly shows that the white race is narrated as a carrier of goodness. As the narrative progresses, what happens next is the claim that good deeds are always associated with white. Regarding this, Foucault explained the concept of white relations and kindness: the desire for racial purity in political empires constructs a discourse of whiteness and allows whites to define themselves as good and pure in relation to the "bad and impure" people of color [9]. In the white savior narrative, images of white morality and superiority are maintained, thus reifying conceptions of racial difference and white goodness [10].

In her conquest in Yunkai, Daenerys argued that she was not the one who freed the slaves. Instead she motivated the slaves to take independence itself. This raises a question: with a large number of slaves, none of them appeared as movers? The savior's white narrative always presents the discourse that non-white people are a marginalized society and that the situation will not change until the savior is present among them. [9] White savior narratives centralize and normalize the white experience through the representation of people of color as unable to escape their social and cultural marginalization without the guidance and leadership of a single white actor (Carrarota, 2010; Hughey, 2010: Shome, 1996).

Slaves managed to free themselves and even killed their masters as a form of revenge after Daenerys encouraged them to do so. Especially with the title Mhysa that they pinned to Daenerys revealed that they only moved from one master to another one and powerful. When Daenerys acts as the queen, she faces a rebel army. The rebels provoked former slaves with writing on the walls that read: kill the masters. Mhysa is a master (S06E01, 00:30:30) [1].

The fire priests in Meereen assumed that Daenerys was the savior they had been hoping for. With a variety of titles that bears her, making the priests amazed and even willing to be loyal supporters of Daenerys. One fire priest once stated that Daenerys was someone who had been promised by their god, Lord of Light. As stated in the following quote,

I was once as you are now. Bought and sold, scourged and branded. The Lord of Light hears your voice. He hears the king as he hears the slave. He hears the Stone Men in their misery. He has sent you a savior. From the fire she was reborn to remake the world. The Dragon Queen! (S05E03, 00:53:30) [1]

The priestess preached before the slaves and preached about the presence of Daenerys or also known as the Dragon Queen. The priest relied on Daenerys hope that one day she would 
save the world with Daenerys' identity as Breaker of Chains and Mother of Dragons. The priestess's words imply that there had been no savior among them, so when Daenerys was present, they expected a lot from her. The priestess also stressed that she was a slave, and with her past she was easily impressed by Daenerys. As stated in [9], without the help of the white savior, Hughey (2010) claims, people of color will not be able to transcend their current social situation.

As stated in the introduction, the narrative of white saviorism is also found in the films Tarzan and Free State of Jones. In both films there are black figures, for example Dr. William in the film Tarzan, played by Samuel L. Jackson. Tarzan is played by a white man (Alexander Skarsgard) who saves the people of Congo, Africa. Hughey [2] argues that both films are hegemonic, because they claim that the film's story is inspired by true stories. If the community believes that the film represents a real event, then the view of the white savior will affect the community. In the film The Help (2011), Wilson [9] examines the white savior narrative in depth. This is related to the representation of black people as helpers in white families. Wilson also examined from the gender side, that in the film, the female servants were more loyal to their employers than their own lives. This is related to the term Mammy Figure, which is the domestication of women in the house, so they do not care about their own lives and take care of the interests of others.

Comparing with the white savior narratives found in the films above, it was revealed that the white savior narratives in the films are also found in the GOT series. Different from the white saviors found in the film Tarzan and Free State of Jones played by men, a woman also has the possibility to become a white savior like Daenerys in the GOT series. One of Daenerys' strategies to gain power was by freeing slaves and punishing their masters. Another case with a white female character named Skeeter in the film The Help, Daenerys uses the white savior's narration to battle power. Whereas Skeeter uses white savior narration as material for writing in her novel. Both of them used black people for certain purposes. The difference is, Daenerys faces the challenges of a patriarchal society where she also struggles to eliminate the stereotypes of always male leaders. While Skeeter is a representation of the unequal fate between herself, a white woman, who graduated from college, and the lives of hermaides who were not progressive.

\section{Conclusion}

The rescue mission carried out by white people is closely related to the concept of white saviorism. The savior felt he had a certain burden because he gained many privileges due to the view of the glory of one race over another race. The contrast of white Daenerys figures raised among non-white slaves implies that the Game of Thrones series is full of white savior narratives. This was confirmed by the rescue and liberation mission carried out by Daenerys to a large number of slaves. Daenerys' release was not purely moral, but a strategy which she played to get the throne and support from former slaves. The title Breaker of Chains and Mhysa is the appreciations from former slaves to Daenerys who freed them. So did Daenerys who used the prestigious titles for her political interests. 


\section{References}

[1] Benioff, David. Weiss, D. (n.d.). Game of Thrones. US: HBO.

[2] Best, K. (2016). The White Savior - Racial Inequality in Film.

[3] FashionLady. (2017). Emilia Clarke Measurements And Bio.

[4] Hartnett, R. (2016). Mhysa or Monster: Masculinization, Mimicry, and the White Savior in A Song of Ice and Fire. Florida Atlantic University.

[5] Hughey, M. W. (2010). The White Savior Film and Reviewers' Reception. Symbolic Interaction. https://doi.org/10.1525/si.2010.33.3.475

[6] Hughey, M. W. (2014). The white savior film: Content, critics, and consumption. In The White Savior Film: Content, Critics, and Consumption. https://doi.org/10.5860/choice.186074

[7] Lovric, Bruno. Hernandez, M. (2019). The House of Black and White: Identities of Color and Power Relations in the Game of Thrones. Revista Nós. Cultura, Estética e Linguagens, v.04 n.02(ISSN 2448-1793), 22.

[8] Martin, G. R. (1996). A Game of Thrones. Bantam Books.

[9] Mobilized Identities: Mediated Subjectivity and Cultural Crisis in the Neoliberal Era. (2014). In Mobilized Identities: Mediated Subjectivity and Cultural Crisis in the Neoliberal Era. https://doi.org/10.18848/978-1-61229-379-0/cgp

[10] Murphy, M. K., \& Harris, T. M. (2018). White Innocence and Black Subservience: The Rhetoric of White Heroism in The Help. Howard Journal of Communications. https://doi.org/10.1080/10646175.2017.1327378

[11] Smith, E. R. (2019). "Mhysa" or Mercy?: Deconstructing 'The White Savior Complex' of Daenerys Targaryen in Game of Thrones ("Mhysa" or Mercy?: Deconstructing "The White Savior Complex' of Daenerys Targaryen in Game of Thrones). Retrieved from https://www.academia.edu/39720519/_Mhysa_or_Mercy_Deconstructing_the_White_Savior_Co mplex_of_Daenarys_Targaryen_in_Game_of_Thrones?auto=download

[12] Young, H. (2014). Race in online fantasy fandom: Whiteness on Westeros.org. Continuum. https://doi.org/10.1080/10304312.2014.941331

[13] K. Saddhono and S. Supeni. "The role of dutch colonialism in the political life of Mataram dynasty: A case study of the manuscript of Babad Tanah Jawi." Asian Soc. Sci. vol. 10 no.15 pp. $1-7,2014$ 